\title{
Heat Shock Protein HSP 90-Alpha
}

National Cancer Institute

\section{Source}

National Cancer Institute. Heat Shock Protein HSP 90-Alpha. NCI Thesaurus. Code C97588.

Heat shock protein HSP 90-alpha (732 aa, $85 \mathrm{kDa}$ ) is encoded by the human HSP90AA1 gene. This protein is involved in the positive regulation of both protein folding and nitric oxide biosynthesis. 